\title{
Tracking the employee satisfaction-life satisfaction binary: The case of South African academics
}

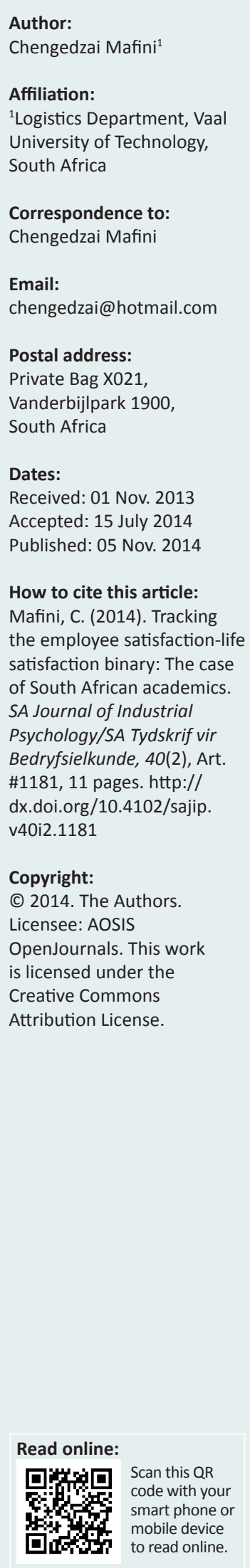

Orientation: The study tests a conceptual framework that suggests a positive interplay between life satisfaction and five employee satisfaction dimensions, namely workplace flexibility, skills utilisation, teamwork, remuneration and autonomy.

Research purpose: The aim of the study was to investigate the relationship between employee satisfaction and life satisfaction amongst university academics in South Africa.

Motivation for the study: The study occupies the gap in literature focusing on the interaction between employee satisfaction and life satisfaction amongst South African university academics.

Research design, approach and method: A three-section survey questionnaire was administered to 273 academics recruited from three universities in Gauteng, South Africa. After a confirmatory factor analysis, hypotheses were tested using a combination of Kendall's tau correlation coefficient and regression analysis.

Main findings: Correlation tests revealed strong positive relationships between life satisfaction and three factors: workplace flexibility, skills utilisation and autonomy. Regression analysis showed that workplace flexibility, skills utilisation and autonomy were statistically significant.

Practical/managerial implications: Research findings could expedite the generation of strategies for meeting the employment needs and expectations of university academics, thereby reducing the shortage of university academics in South Africa.

Contributions/value-add: The conceptual framework proposed in this study is a useful tool for conceptualising the relationship between employee satisfaction and life satisfaction in the higher education environment.

\section{Introduction}

The South African higher education landscape has experienced extensive transformation since the emergence of democracy in 1994. The creation of a three-tier university system consisting of traditional universities, new generation universities and universities of technology, the creation of new regulatory bodies, the changing nature of student and staff distribution, the changing models of instructional delivery and intensified research emphases are some of the hallmark undercurrents characterising these dynamics (Jansen, 2004). The transformations were intended to enable higher education institutions in the country to produce outcomes that are in line with the dynamic needs and demands of the contemporary society (Zohreh, Nadergholi \& Alia, 2011). Be that as it may, the transformation process remains hamstrung by a cocktail of challenges, one of which is the shortage of academics at universities (Council on Higher Education, 2011). This shortage may be attributed, in part, to high attrition rates triggered by the failure to satisfy psychological contracts of such academics (Pienaar \& Bester, 2006). High turnover of academics obviously has severe repercussions for the South African higher education sector, which is currently in its growth stage (Muller, 2013). To address this challenge, most academic institutions in South Africa have had to contend with the momentous task of recruiting and retaining their academics (Samuel \& Chipunza, 2013). A possible solution to this challenge, though, could be to provide employment conditions that facilitate the satisfaction of the needs of university academics, with a view to retaining them.

The purpose of the current study is to investigate the relationship between employee satisfaction and life satisfaction amongst university academics in South Africa. To achieve this, the study measures the impact of five employee satisfaction factors, specifically workplace flexibility, skills utilisation, teamwork, remuneration and autonomy, which have been given emphasis in previous higher education research (e.g. Filiz, 2013; Ignat \& Clipa, 2012; Jusoff, Hussein, Ju \& Din, 2009), on life satisfaction amongst a cohort of South African university academics. There are several 
motivations for conducting this study. Firstly, although research interests focusing on the employee satisfaction of academics are evidently growing, they are dominated by evidence from either Western European or North American environments. Consequently, research is needed in order to understand how employee satisfaction relates to other factors in the context of academics in developing countries such as South Africa. Secondly, a number of previous studies that have examined the subject of satisfying the needs of academics in South Africa (e.g. Nieuwenhuizen, 2011: Rasool \& Botha, 2011; Schulze, 2006) have excluded the dimensions that are examined in this study. As such, the conceptual framework that is put forward in this study is yet to be tested within the South African higher education environment. Thirdly, as suggested by Mokoditoa (2011), the attraction and retention of academics involves, amongst other things, paying particular attention to specific elements of organisational behaviour that are linked to employee motivation. Employee satisfaction and life satisfaction occupy an important niche in organisational behaviour. This presents a need to conduct research that generates knowledge on the behaviour of academics, with the aim of retaining them within the South African academic sector. In sum, it is necessary to continue generating new knowledge on any topic within any discipline of organisational behaviour, in order to update organisational theory (Taylor \& Hansen, 2005).

\section{Review of related literature \\ Research theory}

There are three dominant theoretical explanations accounting for the relationship between employee satisfaction and life satisfaction. The segmentation theory (Loscocco \& Roschelle, 1991) postulates that there is no relationship between employee satisfaction and life satisfaction. The theory is premised on the assumption that job-related variables experienced by employees tend to be kept separate from other non-work activities. The second model is the compensatory theory (Bamundo \& Kopelman, 1980), which assumes that the two constructs are negatively related such that employees who are dissatisfied at work are more likely to compensate for this dissatisfaction by engaging in more satisfying nonwork activities. The third theory is the spillover model, which maintains that there is a positive correlation between employee satisfaction and life satisfaction (Westman, 2006). According to Ilies, Wilson and Wagner (2009), most contemporary research tends to give more support to the spillover theory than to the other two theories. However, despite this empirical support, a contentious and unresolved issue associated with the spillover model relates to the direction of the relationship between employee satisfaction and life satisfaction. Notwithstanding this fact, the spillover model was adopted as the nominal anchor in the current study.

\section{Employee satisfaction}

Scholars have conceptualised employee satisfaction from different viewpoints, culminating in a number of definitions.
Bernhardt, Donthu and Kennett (2000) define employee satisfaction as a personal evaluation of the present conditions of the job as well as outcomes that arise as a result of having a job. Koys (2003) conceptualises employee satisfaction in terms of the employees' perception and evaluation of the job. As defined by Wangenheim, Evanschitzky and Wunderlich (2007), employee satisfaction is a function of the perceived relationship between what one wants from one's job and what one perceives it as offering. Chi and Gursoy (2009) define employee satisfaction in terms of the extent to which employees like their work. The most prevailing precursors to employee satisfaction include environmental antecedents and personal factors (Matzler \& Renzl, 2007). Environmental antecedents include all factors that are associated with the job itself as well as the work atmosphere, whereas personal factors give emphasis to individual attributes and characteristics of employees (Judge, Thoresen, Bono \& Patton, 2001).

It can be argued that the importance of employee satisfaction lies in the fact that organisational success is determined, to a large extent, by the efforts of all employees. Employee satisfaction has been linked to a number of desirable outcomes in the organisation, such as increased quality of outputs and productivity (Faragher, Cass \& Cooper, 2005), enhanced employee confidence, commitment and loyalty (Yee, Yeung \& Cheng, 2008), decreased turnover (Goslin, 2005) and improved organisational citizenship behaviours (Shields, 2006). As such, organisational prosperity is likely to be greater when employee satisfaction is higher. In terms of its measurement, the Minnesota Satisfaction Questionnaire (MSQ) (Spector, 1997) has emerged as arguably the most popular tool for measuring the employee satisfaction. This instrument measures employee satisfaction on 20 five-item scales. Accordingly, this instrument was adopted for the purposes of measuring employee satisfaction in the current study.

\section{Life satisfaction}

There is a general lack of unanimity on the exact definition of life satisfaction. Heller, Judge and Watson (2002) define life satisfaction as an emotional reaction of an individual to life, consisting of work time, spare time and time after work, as well as expressing the individual's satisfaction about life. Rode (2004) conceptualises life satisfaction in terms of the cognitive element of the subjective well-being of people. As defined by Graves, Ohlott and Ruderman (2007), life satisfaction may be perceived as a measure of one's appraisal of life in general. Ye, Yu and Li (2012) define life satisfaction as an individual's evaluation about their quality of life. Rode's definition was adopted for the present study since it focuses primarily on employees.

Primary antecedents to life satisfaction include personality, genetic and social-cognitive factors such as goaldirected activity, self-efficacy, outcome expectations and environmental support (Buetell, 2006). Other conditions that influence life satisfaction include demographic, 
environmental and interpersonal factors (Koohsar \& Bonab, 2011). Furthermore, taking pleasure in life, finding life meaningful, consistency on the matter of reaching goal satisfaction, positive individual identity, physical fitness, economic security and social relationships are all important life satisfaction indicators (Judge et al., 2001; Lent, Taveira, Sheu \& Singley, 2009; Saari \& Judge, 2004).

Life satisfaction is positively related to a number of personal and work-related factors that include inter alia selfmotivation, optimism and resilience (Palmer, Donaldson \& Stough, 2002), commitment and loyalty (Nickerson \& Nagle, 2005), high productivity (Guney, Kalafat \& Boysan, 2010), high employee satisfaction (Bastug \& Duman, 2010), quality of work life (Ozer \& Saçke, 2011) and improved family and peer relations (Zhang \& Howell, 2011). In view of this, it is an important possibility that organisations stand to reap immense benefits by cultivating high levels of life satisfaction amongst their human resources. In terms of its measurement, the Satisfaction with Life Scale (SWLS) developed by Diener, Emmons, Larsen and Griffin (1985) has stood out as the most popular tool for measuring life satisfaction. This instrument was therefore adopted for the purposes of measuring life satisfaction in the current study.

\section{Employee satisfaction and life satisfaction}

The relationship between employee satisfaction and life satisfaction has been a subject of prominence for a host of research practitioners (e.g. Cummings \& Worley, 2005; Eskildsen \& Dahlgaard, 2000; Georgellis, Lange \& Tabvuma, 2012; Mafini, Surujlal \& Dhurup, 2012). In general, employee satisfaction is regarded as an antecedent to the overall life satisfaction of employees to the extent that employees who are not happy in their non-work activities will not be happy in their work activities (Ghiselli, La Lopa \& Bai, 2001; Zhao, Qu \& Ghiselli 2011). The same results have been noted within the realm of academia. For instance, Jusoff et al. (2009) found a positive association between the employee satisfaction and life satisfaction of both academic and non-academic staff in a Malaysian higher education institution. A positive interconnection between employee and life satisfaction was also observed in a study conducted amongst academic staff at a Turkish university (Feliz, 2013). Moreover, the results of a study conducted by Ignat and Clipa (2012) that sampled Romanian academics confirms the existence of a positive relationship between employee satisfaction and life satisfaction. Therefore, employees in academia and beyond who have a positive perception of their jobs typically evaluate their overall well-being in life better and are likely to be more satisfied with their life in general.

\section{Employee satisfaction factors and life satisfaction}

As has been highlighted before, employee satisfaction can be measured through at least 20 sub-factors. However, there currently exists a wide body of scholarly research that appears to place major emphasis on workplace flexibility, skills utilisation, teamwork, remuneration and autonomy as central employee satisfaction factors that determine life satisfaction in the higher education environment. For example, studies by Cech and Blair-Loy (2014), Pienaar and Bester (2006) and Phillips and Connell (2003) point to workplace flexibility as a factor of significant importance for many faculty members in that it has a strong impact on life satisfaction, job loyalty and organisational citizenship, amongst other factors. With reference to skills utilisation, some studies focusing on employee satisfaction (e.g. Johnsrud, 2002; Volkwein \& Zhou, 2003) classify skills utilisation amongst intrinsic motivators that are essential ingredients for satisfaction in other areas of an academic's life. Schulze (2006) likewise identifies high skills utilisation as one of the numerous factors that can have a positive influence on the life satisfaction of academic staff members. Additionally, Holub (2003) concludes that the level of life satisfaction that is experienced by university lecturers is greatly influenced by various determinants, amongst them skills utilisation.

In terms of remuneration, a number of studies (Kipkebut, 2010; Rosser, 2004; Shoaib, Noor, Tirmizi \& Bashir, 2009; Tettey, 2006) conducted within various academic environments have established that remuneration is associated with other employee-related factors such as life satisfaction, productivity, job security and general well-being. In respect of teamwork, the results of studies conducted by a number of scholars (Abdullah, Ahsan, Yong Gun Fie \& Shah Alam, 2009; Riley, 2009) reveal that academic staff members are likely to experience stress, low employee and life satisfaction as a result of a lack of a camaraderie in the workplace. In previous research carried out by Weiss (2002), the lack of teamwork was found to be one of the factors contributing to the deep feeling of pessimism that is heavily pronounced amongst academics at South African higher education institutions. With regard to autonomy, the findings of several studies (Daly \& Dee, 2006; Dockel, 2003; Ngethe, Iravo \& Namusone, 2012) attest that autonomy is positively linked to life satisfaction of academics, through its stimulus effect on the satisfaction of higher order needs for achievement and accomplishment.

The literature reviewed in the foregoing sections presupposes the existence of affirmative associations between employee satisfaction factors and life satisfaction amongst academics. These presuppositions make it logical to anticipate significant positive relationships between life satisfaction and the specified employee satisfaction factors. Therefore, the following hypotheses within the present study are put forward.

Hypothesis 0: Life satisfaction is not significantly and positively related to the five employee satisfaction factors, namely workplace flexibility, skills utilisation, teamwork, remuneration and autonomy, amongst academics.

Hypothesis 1: There is a significant positive relationship between workplace flexibility and life satisfaction amongst academics. 
Hypothesis 2: There is a significant positive relationship between skills utilisation and life satisfaction amongst academics.

Hypothesis 3: There is a significant positive relationship between teamwork and life satisfaction amongst academics. Hypothesis 4: There is a significant positive relationship between remuneration and life satisfaction amongst academics.

Hypothesis 5: There is a significant positive relationship between autonomy and life satisfaction amongst academics.

\section{Conceptual framework}

The conceptual framework illustrated in Figure 1 is proposed, which reveals the linkage between the five employee satisfaction dimensions and life satisfaction.

\section{Research design and methodology Research design}

In the current study, a quantitative design using a crosssectional survey method was adopted. The survey method was utilised because of its empirical nature, the ability to produce a large amount of data in a short time at a low cost and the fact that it allows for the generalisation of results since it has a broader breadth of coverage of people or events (Story, Ranong \& Jones, 2011).

\section{Research method}

\section{Participants and sampling}

The sample used in this study was made up of 273 academics drawn from three universities (two traditional universities and a university of technology) located in the Gauteng province of South Africa. Respondents were selected using the non-probability convenience sampling technique. The convenience sampling technique was deemed appropriate for this study as it was difficult to locate the academics at the same place and time due to their busy work schedules. The sample size was determined using Green's (1991) rule of thumb, which specifies that a minimum of 50 respondents are sufficient for a correlation or regression, with the number increasing as the number of independent variables (IVs) increases. The implication of Green's rule in the current study is that a minimum of 250 respondents was required since five independent variables were used. Based on this prescription, the eventual sample size of 273 was considered

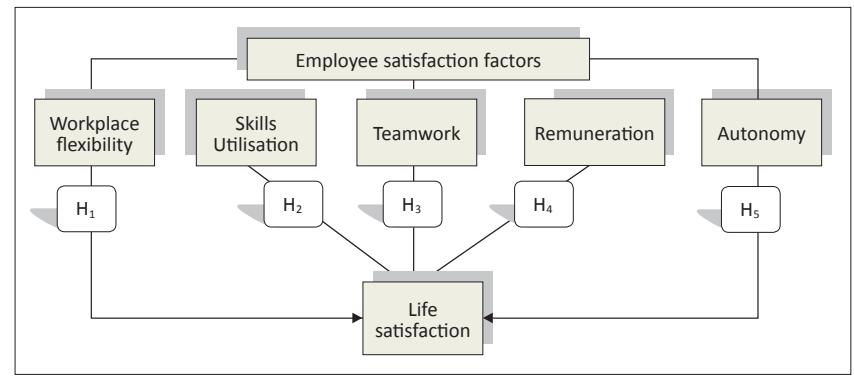

FIGURE 1: Conceptual framework for employee satisfaction and life satisfaction. The framework depicts that workplace flexibility, skills utilisation, teamwork, remuneration and autonomy are employee satisfaction dimensions, all of which are positively related to life satisfaction. satisfactory for the purposes of the study. The demographic characteristics of the respondents are illustrated in Table 1.

An analysis of the demographic profile of respondents (Table 1) reveals that approximately 59\% $(n=162)$ of the respondents were male whereas approximately $41 \%$ $(n=111)$ were female. After collapsing the respondents' ages, it emerged that the largest group of respondents (81\%; $n=220$ ) were aged between 26 and 45 years. Additionally, approximately $47 \%(n=127)$ of the respondents were in possession of a master's degree. In terms of racial group, black people $(53 \% ; n=144)$ were the highest number. With regard to the position occupied, the largest group of respondents $(45 \% ; n=123)$ was lecturers, followed by junior lecturers $(23 \% ; n=62)$, with full professors $(3 \% ; n=7)$ being the smallest number.

\section{Data collection procedures and measurement instruments}

Data were collected through the use of a three-section selfadministered questionnaire. Section-A of the questionnaire requested the respondents to provide their demographic information. In Section-B, respondents were requested to indicate their level of employee satisfaction on a five-point Likert scale which ranged from 1 (very dissatisfied) to 5 (very satisfied). An adapted version of the validated MSQ (Spector, 1997) was used in this section. Section-C used the SWLS (Diener et al., 1985) to elicit responses regarding the respondents' perceived level of well-being and happiness. Since life satisfaction is a complex construct that has to be assessed within a specific context (Chang \& Sanna, 2001), the

TABLE 1: Demographic profile of respondents $(N=273)$.

\begin{tabular}{|c|c|c|c|}
\hline Variable & Categories & $N$ & $\%$ \\
\hline \multirow[t]{2}{*}{ Gender } & Male & 162 & 59.23 \\
\hline & Female & 111 & 40.77 \\
\hline \multirow[t]{4}{*}{ Age group } & $\leqq 25$ & 17 & 6.25 \\
\hline & $26-35$ & 119 & 43.61 \\
\hline & $36-45$ & 101 & 36.99 \\
\hline & $\geqq 45$ & 36 & 13.19 \\
\hline \multirow[t]{4}{*}{ Duration of employment } & $\leqq 2$ years & 55 & 20.31 \\
\hline & $2-5$ years & 77 & 28.13 \\
\hline & $6-9$ years & 94 & 34.38 \\
\hline & $\geqq 9$ years & 47 & 17.19 \\
\hline \multirow{5}{*}{$\begin{array}{l}\text { Highest educational } \\
\text { qualification }\end{array}$} & Bachelor's degree & 15 & 5.37 \\
\hline & Honours degree & 66 & 24.19 \\
\hline & Master's degree & 127 & 46.61 \\
\hline & Doctoral degree & 48 & 17.74 \\
\hline & $\begin{array}{l}\text { Other (e.g. professional } \\
\text { qualifications) }\end{array}$ & 17 & 6.09 \\
\hline \multirow[t]{5}{*}{ Racial group } & Black & 144 & 52.75 \\
\hline & White & 69 & 25.27 \\
\hline & Indian & 47 & 17.22 \\
\hline & Mixed-race & 9 & 3.30 \\
\hline & Other (e.g. Chinese) & 4 & 1.47 \\
\hline \multirow[t]{6}{*}{ Current position } & Junior lecturer & 62 & 22.71 \\
\hline & Lecturer & 123 & 45.05 \\
\hline & Senior lecturer & 48 & 17.58 \\
\hline & Associate professor & 22 & 8.06 \\
\hline & Full professor & 7 & 2.56 \\
\hline & Other (e.g. researcher) & 11 & 4.03 \\
\hline
\end{tabular}


work environment was used for this study. Likert scales were used in Sections-B and Section-C because they offer a number of advantages such as simplicity, versatility, universal applicability, greater accuracy and ease of administration (Carifio \& Perla, 2007).

Before its administration, the items in the questionnaire were reviewed by three academics from a South African university of technology who are experts in the field of industrial psychology. In addition, a pretest was conducted using a conveniently selected sample of 20 academics. The feedback obtained from both the panel of experts and the pretest sample was used as the basis for adapting the questionnaire in order to ensure that it would validly capture the required information, in accordance with Olson's (2010) recommendation that questionnaire adaptation ought to be based on the input from both expert reviewers and the pretest sample. The amendments included substantive adjustments to such aspects as language used, grammar, the level of difficulty in each question and reduction in the number of items used. More to this, only items that are relevant to the constructs examined in this study were used. Eventually, Section-A of the questionnaire consisted of six questions (Table 1) whilst Section-B consisted of 25 questions (Table 2). The final distribution of questions in Section-B was as follows: four items for workplace flexibility, five items for skills utilisation, four items for teamwork, four items for remuneration, three items for autonomy and five items for life satisfaction.

Data collection was conducted between January 2013 and March 2013. Prior to the administration of the questionnaire, permission to conduct the study was sought and granted by the ethical committees of the three institutions involved. Two trained postgraduate students at the Vaal University of Technology were employed as research assistants. The students were paid using funds availed through the Research Stimulation Fund at the university of technology. Contacts established at the three institutions were also instrumental in assisting in the distribution of the questionnaires. Respondents participated in the study on a voluntary basis and were assured that the information they provided would be used solely for academic purposes and that their identities would remain anonymous at all times. Out of the 450 questionnaires that were initially distributed, 284 questionnaires were returned. However, 11 questionnaires were eliminated in the screening process because they were either incomplete or had more than one response on a number of questions and were thus spoiled. Ultimately, 273 questionnaires were used in the data analysis, giving a response rate of approximately $61 \%$, which satisfies Fincham's (2008) recommendation that a minimum response rate of $60 \%$ is necessary to ensure credible results in a survey.

\section{Analysis of the results}

Data analysis was conducted using a combination of the Statistical Packages of the Social Sciences (SPSS version 21.0) and AMOS 15 software. The results obtained in the current study are presented in the following configuration: the confirmatory factor analysis is presented first, followed by the psychometric properties of the constructs. This is succeeded by a section detailing the results of the correlation analysis and regression analysis.

\section{Confirmatory factor analysis}

Since the scales used in this study were validated in other contexts, confirmatory factor analysis (CFA) using AMOS 15.0 software was performed in order to ensure that these scales were in fact relevant and reliable within a South African context. The CFA and the model fit of the constructs with multiple indicators (workplace flexibility, skills utilisation, teamwork, remuneration and autonomy) were determined to be acceptable. A number of indices suggested by Bagozzi and $\mathrm{Yi}$ (1998) were adopted for the purposes of assessing the model fit. These included CMIN/DF $(<0.3)$, goodness-offit index (GFI $\geq 0.90)$, comparative fit index (CFI $\geq 0.90$ ), Tucker and Lewis index (TLI $\geq 0.90)$ and root mean square error of approximation (RMSEA $\leq 0.08$ ). The CMIN/DF was 1.810, GFI 0.920, CFI 0.961, TLI 0.948 and RMSEA 0.06, which indicates satisfactory fit of the model (Hulland, 1999).

\section{Psychometric properties of constructs}

The means, standard deviations, inter-construct correlations, square root of average variance extracted (AVE) scores, standardised factor loadings and composite reliability (CR) estimates are reported in Table 2.

As shown in Table 2, Cronbach's alpha values for all constructs were satisfactory, ranging from 0.736 to 0.864 . Furthermore, CR estimates ranged from 0.836 to 0.945 , which indicates acceptable construct reliability. All items loaded strongly (i.e. all standardised loadings $>0.50$ ) and significantly $(p<0.01)$ on respective constructs. Thus, adequate construct validity can be assumed in the current study. Clark and Watson (1995) suggest that a valid measure of a construct requires inter-item correlations in the range of 0.40 to 0.50 . The inter-item correlations ranged from 0.511 to 0.749 for all the constructs, thereby providing evidence of construct validity. A measure is said to possess convergent validity if the instrument correlates highly with other variables with which it should theoretically correlate (Leo, Bennet \& Hartel, 2005). Convergent validity was assessed using the average variance extracted from each construct, which were well above 0.5 (Chin, 1998), thereby affirming convergent validity. Content and face validities were ascertained in the pretest of the questionnaires. Predictive validity was assessed through regression analysis (Table 4), in which three of the five employee satisfaction factors were statistically significant, thereby reflecting sufficient levels of predictive validity in the scale.

A further analysis of Table 2 reveals that mean scores ranging between 3.189 and 3.974 (out of 5.0) were computed for all the constructs examined in the study. These scores depict a collective inclination towards both the 'agree' and 'strongly agree' positions on the Likert scale, which demonstrates 
that the academics had satisfactory levels of both employee satisfaction and life satisfaction. Skills utilisation $(\bar{x}=3.974$; $P<0.05)$ emerged as the highest-ranking factor in terms of the mean scores, followed by workplace flexibility $(\bar{x}=3.812$; $P<0.05)$, remuneration $(\bar{x}=3.673 ; P<0.05)$, autonomy $(\bar{x}=3.547 ; P<0.05)$ and teamwork $(\bar{x}=3.189 ; P<0.05)$. This result implies that academics were more satisfied with skills utilisation and least satisfied with teamwork amongst the five employee satisfaction factors extracted in the study.

\section{Correlations: Employee satisfaction and life satisfaction}

The Kendall's tau correlation coefficient (Agresti, 2010) was used to examine the strength and direction of the association between the five employee satisfaction domains and life satisfaction. The results are presented in Table 3.

An analysis of the correlation matrix (Table 3) reveals that there were positive correlations, anchored by a $\tau$ value of $0.26(P<0.900)$ and a $\tau$ value of $0.78(P<0.059)$, between life satisfaction and all five employee satisfaction factors. This result shows that an increase in any one employee satisfaction factor can actuate increases in life satisfaction amongst university academics. In contrast, any decrease in any employee satisfaction factor may lead to a decrease in life satisfaction.

\section{Regression analysis: Employee satisfaction and life satisfaction}

Since there were positive associations between the five employee satisfaction dimensions and life satisfaction, multiple regression analysis using the 'enter' method (Malhotra, 2010) was employed to ascertain whether the employee satisfaction factors predicted life satisfaction. A principal assumption that was made to justify the use of linear regression analysis for purposes of predicting the existence of relationships amongst the constructs is the existence of linearity between employee satisfaction factors and life satisfaction. $\mathrm{V}$ ariance inflation factor (VIF) values ranged between 1.156 and 2.210, which is within the maximum permissible threshold of 10, as prescribed by Field (2009). Additionally, tolerance values ranged between 0.509 and 0.795 , which were acceptable since they were above the recommended minimum of 0.5 (Denis, 2011). Therefore, multicollinearity diagnosis did not signal a serious threat, which made a regression analysis both feasible and appropriate. The results of the regression analysis are reported in Table 4.

Table 4 reflects that the adjusted $R^{2}$ was 0.428 , which denotes that employee satisfaction explained approximately $43 \%$ of the variance in life satisfaction. The remaining $57 \%$ is

TABLE 3: Kendall's tau correlation coefficients for association between employee satisfaction and life satisfaction.

\begin{tabular}{lcc}
\hline Employee satisfaction variables & \multicolumn{2}{c}{ Life satisfaction } \\
\cline { 2 - 3 } & $\boldsymbol{T}$ & $\boldsymbol{P}$ \\
\hline Workplace flexibility & 0.61 & $0.100^{\mathrm{a}}$ \\
Skills utilisation & 0.78 & $0.059^{\mathrm{a}}$ \\
Teamwork & 0.26 & 0.900 \\
Remuneration & 0.43 & 0.705 \\
Autonomy & 0.66 & $0.059^{\mathrm{a}}$ \\
\hline
\end{tabular}

a, Correlation is significant at the 0.01 level.

TABLE 2: Composite reliability and accuracy analysis statistics.

\begin{tabular}{|c|c|c|c|c|c|c|c|c|c|}
\hline \multirow[t]{2}{*}{ Research constructs } & \multirow[t]{2}{*}{ Scale items } & \multicolumn{2}{|c|}{ Descriptive statistics } & \multicolumn{2}{|c|}{ Reliability tests } & \multirow[t]{2}{*}{ CR } & \multirow[t]{2}{*}{ AVE } & \multirow{2}{*}{$\begin{array}{l}\text { Factor } \\
\text { loadings }\end{array}$} & \multirow[t]{2}{*}{ Highest SV } \\
\hline & & Mean & Mean score rank & Item-total & $\alpha$-value & & & & \\
\hline \multirow[t]{4}{*}{ Workplace flexibility (WF) } & WF-1 & 3.812 & 2 & 0.605 & 0.864 & 0.836 & 0.588 & 0.724 & 0.160 \\
\hline & WF-2 & - & - & 0.727 & - & - & - & 0.858 & - \\
\hline & WF-3 & - & - & 0.618 & - & - & - & 0.710 & - \\
\hline & WF4 & - & - & 0.652 & - & - & - & 0.861 & - \\
\hline \multirow[t]{5}{*}{ Skills utilisation (SU) } & SU-1 & 3.974 & 1 & 0.511 & 0.753 & 0.865 & 0.595 & 0.519 & 0.381 \\
\hline & SU-2 & - & - & 0.738 & - & - & - & 0.859 & - \\
\hline & SU-3 & - & - & 0.749 & - & - & - & 0.892 & - \\
\hline & SU-4 & - & - & 0.666 & - & - & - & 0.762 & - \\
\hline & SU-5 & - & - & 0.533 & - & - & - & 0.735 & - \\
\hline \multirow[t]{4}{*}{ Teamwork (TW) } & TW-1 & 3.189 & 6 & 0.519 & 0.771 & 0.884 & 0.689 & 0.795 & 0.265 \\
\hline & TW-2 & - & - & 0.634 & - & - & - & 0.885 & - \\
\hline & TW-3 & - & - & 0.553 & - & - & - & 0.808 & - \\
\hline & TW-4 & - & - & 0.609 & - & - & - & 0.843 & - \\
\hline \multirow[t]{4}{*}{ Remuneration (RM) } & RM-1 & 3.673 & 3 & 0.721 & 0.814 & 0.945 & 0.636 & 0.809 & 0.251 \\
\hline & $\mathrm{RM}-2$ & - & - & 0.593 & - & - & - & 0.749 & - \\
\hline & $\mathrm{RM}-3$ & - & - & 0.667 & - & - & - & 0.725 & - \\
\hline & RM-4 & - & - & 0.707 & - & - & - & 0.694 & - \\
\hline \multirow[t]{3}{*}{ Autonomy (AU) } & $\mathrm{AU}-1$ & 3.547 & 4 & 0.543 & 0.736 & 0.945 & 0.597 & 0.735 & 0.193 \\
\hline & $\mathrm{AU}-2$ & - & - & 0.527 & - & - & - & 0.674 & - \\
\hline & $A U-3$ & - & - & 0.571 & - & - & - & 0.513 & - \\
\hline \multirow[t]{5}{*}{ Life satisfaction (LS) } & LS-1 & 3.275 & 5 & 0.568 & 0.791 & 0.912 & 0.622 & 0.761 & 0.346 \\
\hline & LS-2 & - & - & 0.722 & - & - & - & 0.716 & - \\
\hline & LS-3 & - & - & 0.649 & - & - & - & 0.577 & - \\
\hline & LS-4 & - & - & 0.675 & - & - & - & 0.521 & - \\
\hline & LS-4 & - & - & 0.586 & - & - & - & 0.752 & - \\
\hline
\end{tabular}

CR, composite reliability; AVE, average variance extracted; SV, shared variance. 
TABLE 4: Regression analysis: Employee satisfaction and life satisfaction.

\begin{tabular}{lccccc}
\hline $\begin{array}{l}\text { Independent } \\
\text { variable: } \\
\begin{array}{l}\text { Employee } \\
\text { satisfaction }\end{array}\end{array}$ & Beta & $T$ & Significance & \multicolumn{3}{c}{ Collinearity statistics } \\
\cline { 2 - 6 } & & & & Tolerance & VIF \\
\hline Workplace flexibility & 0.324 & 4.615 & 0.001 & 0.509 & 1.156 \\
Skills utilisation & 0.227 & 2.427 & 0.000 & 0.576 & 1.396 \\
Teamwork & -0.243 & -3.755 & 0.156 & 0.582 & 1.177 \\
Remuneration & 0.056 & 1.326 & 0.789 & 0.619 & 2.210 \\
Autonomy & 0.186 & 1.219 & 0.000 & 0.795 & 1.367 \\
\hline
\end{tabular}

$R=0.475$; Adjusted $R^{2}=0.428 ; F=13.677$.

$\mathrm{VIF}$, variance inflation factor

accounted for by other factors that were not examined in this study.

\section{Discussion}

Hypothesis 1 was supported and subsequently accepted in the present study. For confirmation, the results of the correlation analysis exhibited a strong positive correlation ( $\tau=0.61 ; P=0.100)$ between workplace flexibility and life satisfaction. Complimentary to this, in the regression analysis, workplace flexibility $(\beta=0.324 ; t=4.615$; $P<0.001)$ emerged as statistically significant. The finding of the correlation analysis demonstrates that the life satisfaction of academics increases as workplace flexibility increases. Furthermore, the result of the regression analysis illustrates that workplace flexibility is an indicator of life satisfaction amongst academics. Flexible working is associated with a number of positive outcomes that tend to boost life satisfaction amongst academics. For instance, Goulden, Mason and Frasch (2011) found that flexible working was a positive factor in achieving better work-life balance amongst faculty staff. The majority of academics in a study conducted by Drago et al. (2006) reported that flexible working had a positive effect in reducing and managing stress levels, which tends to increase life satisfaction. Flexible employees were found to have higher levels of both employee satisfaction and life satisfaction in a study conducted by Turkyilmaz, Akman, Ozkan and Pastuszak (2011). Workplace flexibility has been associated with job security of academics as well as the opportunity to embark on personal and professional development programs (Bunton \& Corrice, 2011). Mederer and Silver (2011) further advocate that workplace flexibility is a reliable instrument for the attraction, retention, engagement, wellness and productivity of top academic talent. It appears then that workplace flexibility occupies an important place as a tool for meeting the needs of academic faculty staff.

Hypothesis 2 found support and was accepted in the present study. This decision was premised on the fact that the correlation matrix indicated a strong positive association ( $\tau=0.78 ; P=0.059$ ) between skills utilisation and life satisfaction. Further to this, the scores in the regression analysis indicate that skills utilisation $(\beta=0.227 ; t=2.427$; $P<0.000)$ is statistically significant. The result of the correlation analysis implies that life satisfaction amongst academics increases with an increase in the extent to which the skills of these academics are used in the workplace.
The result of the regression analysis shows that the degree to which the competencies or skills of academics are utilised is an important reflector of the extent to which the same academics are satisfied with life. Consistent with this finding, a study by Chung et al. (2010) concludes that increased opportunities for faculty members to apply their abilities at work may result in higher levels of life satisfaction. In an earlier study conducted by Zarafshani and Alibaygi (2008), skills utilisation was found to be a significant predictor of both employee satisfaction and life satisfaction of Iranian academics. Additionally, a study by Bender and Heywood (2006) that investigated satisfaction levels of PhD-level academics reveals a positive interconnection between skills utilisation and life satisfaction. In the African context, intrinsic facets of work, inclusive of skills utilisation were found to be indicators of the life satisfaction of Ugandan academics (SSesanga \& Garret, 2005). It is a logical supposition then that in order to enhance the life satisfaction of academic employees, one has to positively adjust their degree of skills utilisation.

With regard to teamwork, Hypothesis 3 was not supported and was therefore rejected. For endorsement of this outcome, reference is given to the correlation matrix, which revealed a weak correlation $(\tau=0.26 ; P=0.900)$ between teamwork and life satisfaction. Consistently, teamwork $(\beta=-0.243$; $t=-3.757 ; P<0.156)$ was statistically insignificant in the regression analysis. The results of the correlation analysis suggest that when teamwork amongst academics increases, there will be very insignificant (immaterial) changes in their life satisfaction. The negative beta associated with teamwork in the regression model indicates that teamwork cannot be used as an indicator for life satisfaction amongst academics. It appears that teamwork does not seem to influence the life satisfaction of academics in the context of the present study. This result may be astonishing, since it contradicts the conventional view that teamwork within the organisation is an indispensable stimulant of both employee and organisational performance (Griffin, Patterson \& West, 2001; Kalisch, Lee \& Rochman, 2010; Turman, 2003). A plausible explanation for this result could be the existence of manifest conflict amongst academics who work in the same institution. It is well acknowledged that:

debate and dissent are the lifeblood of universities and some of our greatest scholars pride themselves on being uncompromising, which makes conflict inevitable in such situations from time to time. (West, 2006, p. 187)

Debates and controversies are commonplace within academic circles. Intellectual competition is also rife as academics jostle for intellectual honours associated with the profession (Hyland, 2009). As noted by Volpe and Chandler (2001), even collaborations between academics can be associated with a plethora of challenges as divergent opinions emerge. To avoid conflict stemming from partnerships, some academics tend to prefer collaborating with academics from other institutions rather than with those from their own institutions (Clark, 2004). The existence of conflicting personalities and perspectives amongst academics compels 
some to resort to individual efforts, rather than teamwork (White \& Lowenthal, 2011). Issues of compatibility with each other also emerge as the academic arena in South Africa has become very diverse in terms of age, race and even nationality (Mayekiso \& Snodgrass, 2008). Such complexities tend to stifle teamwork amongst academics, resulting in a weak relationship between teamwork and life satisfaction amongst academics. Measures have to be implemented to ensure that teamwork or partnering occupies its rightful place as a promoter of employee satisfaction and life satisfaction in academic circles.

Hypothesis 4 received partial support in this study. As evidence for this outcome, a moderate positive correlation ( $\tau=0.43 ; P=0.705)$ was observed between remuneration and life satisfaction. However, the regression matrix indicated that remuneration $(\beta=0.056 ; t=1.326 ; P<0.789)$ was not a statistically significant predictor of life satisfaction. The results of the correlation analysis denote that changes in the levels of remuneration are likely to trigger moderate (neither low nor high) changes in the life satisfaction of academics. Despite this positive association, the results of the regression analysis disclose that remuneration is not an indicator (predictor) of the life satisfaction of academics. The findings of the current study seem to confirm the respected traditional opinion by Herzberg (1966) that money is a hygiene (essential) factor but is not a motivator. In parallel, Amar (2004) concludes that the ability of money to motivate skilled employees is almost negligible. In a recent study by Samuel and Chipunza (2013), it was found that remuneration does not influence the turnover of South African academics. As such, the findings of the current study do not seem to be surprising. Notwithstanding this fact, it may be interesting to note that there is a disparity in the remuneration of lowerlevel and senior academics in South Africa. For instance, the entry-level remuneration for academics in South Africa remains depressed (Kgosana, 2011). On the other end, the remuneration of top-level academics in South Africa remains competitive when compared with countries such as the United Kingdom, United States, Canada and Australia (Jansen, 2013). It is possible then that this existent dichotomy places strain on the extent to which remuneration as an employee satisfaction factor is able to predict life satisfaction. For instance, the lowly paid entry-level academics may be less satisfied with life, in contrast with the highly paid toplevel academics, which may create a mismatch between the performances of the two cohorts.

In the present study, Hypothesis 5 found support and was accepted. To sustain this decision, a strong positive association between autonomy $(\tau=0.66 ; P=0.059)$ and life satisfaction was observed in the correlation analysis. Autonomy also emerged as statistically significant $(\beta=0.186$; $t=1.219 ; P<0.000)$ in the regression analysis. The results of the correlation test indicate that significant increases in the life satisfaction of academics can be observed when the degree of their autonomy at work is enhanced. The results of the regression analysis demonstrate that the level of autonomy amongst academics is an important indicator of the depth of life satisfaction amongst these academics. The findings of the current study are in line with previous research by a number of scholars (Finn, 2001; Martensen \& Gronholdt, 2001; Turkyilmaz et al., 2011) who found that autonomy was a significant factor that contributed to both employee satisfaction and life satisfaction. Moreover, it is natural for academics to require high levels of autonomy. In South Africa, Section 16 of the Constitution (1996) offers specific protection to the autonomy of academics through the support of academic freedom in higher education. Moreover, as highlighted by Slabbert (2003), the lack of autonomy in higher education institutions is a worrisome issue because the intellectual life of academics is about the non-stop subversion of orthodoxy and dogmatism. As such, management practices that include the micromanaging of academics or subjecting them to successions of operational rules in their line of work would have a negative impact on their well-being at work (Oshagbemi, 1996). It is a normal expectation, then, that academics would feel satisfied in their jobs and with their lives when they enjoy a high degree of freedom in the execution of their duties.

\section{Limitations and implications for further research}

Although the findings of the present study constitute an up-to-date source of knowledge and information on the relationship between employee satisfaction and life satisfaction amongst university academics, two limitations associated with the study are worth mentioning. It is expected that the findings of the study cannot be generalised to other geo-spatial contexts, since the results are based on a limited sample of 273 academics that were based at three South African institutions only. Another limitation is the use of the convenience sampling technique, which increased the study's susceptibility to sampling bias.

Several implications for further research can be highlighted. The study could be replicated using amplified sample sizes drawn from other universities that were not included in this study. Future studies could also examine the relationship between individual employee satisfaction factors and life satisfaction. The relationship between specific demographic factors such as gender, employment period, type of employment, level of education, age group and either employee satisfaction or life satisfaction provides fertile ground for possible future studies. It would also be interesting to conduct longitudinal studies on the same subject, so that trends on the employee satisfaction-life satisfaction nexus within the South African academic environment can be captured at different periods of time. Future research endeavours could examine the relationship between employee satisfaction and life satisfaction amongst academics using other employee satisfaction factors that were not used in the current study.

\section{Managerial implications}

Managers in higher education institutions could refer to the findings of the study for information in solving 
problems related to labour relations, motivation and human performance within the rank and file of academics. Since both employee satisfaction and life satisfaction are positively associated with a multiplicity of desirable personal and organisational outcomes, the expediting of these factors is likely to have a stimulus effect on the outcomes. Academic institutions should reinvent their cultures by the adoption of contemporary best practice that includes such activities as the continued entrenchment of flexitime, reduced workloads (e.g. fewer students and teaching hours) and increased time off for academics to address personal and family issues, sick leave, paid time off to care for children, sabbaticals and virtual offices (working from home) in order to enhance workplace flexibility (Friedman, 2012).

Regular employee satisfaction surveys may be necessary to tap the views of academics on their perceptions on the extent to which their skills are being used in their environments (Riddell, Edward, Raffe, Tett \& Weedon, 2008). To improve remuneration, salaries should be increased to attract and retain academics in all levels of the hierarchy. The stimulation of academic entrepreneurship could be adopted to provide third-stream income to all academics. Furthermore, funds earned from research efforts can be availed as income to the academics involved. To bolster teamwork amongst academics, interventions such as team building programs could be implemented on a regular basis to encourage more teamwork and to flush out the dysfunctional aspects associated with current teamwork efforts (Ogbonna \& Harris, 2004). To enhance autonomy, it is necessary for managers to cultivate environments in which academic freedom is promoted amongst academics, so that academics can be free to apply their intellectual resources without fear of censure. Individual efforts and innovation could also be encouraged in academic institutions and those that excel in these endeavours should be rewarded openly.

\section{Conclusions}

The aim of this study was to investigate the relationship between employee satisfaction and life satisfaction. The study was conducted within the ambit of university academics in South Africa, using five employee satisfaction factors, namely workplace flexibility, skills utilisation, teamwork, remuneration and autonomy. Academics were most satisfied with skills utilisation and least satisfied with the level of teamwork. The results of the correlation analysis showed strong positive associations between life satisfaction and three employee satisfaction factors, namely workplace flexibility, skills utilisation and autonomy. A moderate positive correlation was observed between remuneration and life satisfaction and a weak positive correlation was observed between teamwork and life satisfaction. In the regression analysis, it emerged that workplace flexibility, skills utilisation and autonomy were significant predictors of life satisfaction amongst academics. Based on the foregoing results, two primary conclusions can be made that address the aim of the study. Firstly, the employee satisfaction of university academics is positively associated with their life satisfaction. As such, the degree of life satisfaction amongst university academics runs parallel to their existing levels of employee satisfaction. Secondly, employee satisfaction amongst university academics predicts, albeit partially, their life satisfaction. This means that some employee satisfaction factors (in this case workplace flexibility, skills utilisation and autonomy) may be used as indices for life satisfaction, whereas some factors (in this case teamwork and remuneration) may not serve as indicators of the life satisfaction of academics.

\section{Acknowledgements}

The author would like to thank the Research Office at the Faculty of Management Sciences (Vaal University of Technology, South Africa) for providing the funding for this project.

\section{Competing interests}

The author declares that he has no financial or personal relationship(s) that may have inappropriately influenced him in writing this article.

\section{References}

Abdullah, Z., Ahsan, N., Yong Gun Fie, D., \& Shah Alam, S. (2009). A study of job stress on job satisfaction among university staff in Malaysia: An empirical study. European Journal of Social Sciences, 8(1), 121-131.

Agresti, A. (2010). Analysis of ordinal categorical data. (2nd edn.). New York, NY: John Wiley \& Sons. http://dx.doi.org/10.1002/9780470594001

Amar, A.D. (2004). Motivating knowledge workers to innovate: A model integrating motivation dynamics and antecedents. European Journal of Innovation Management, 7(2), 89-101. http://dx.doi.org/10.1108/14601060410534366

Bagozzi, R.P., \& Yi, Y. (1998). On the evaluation of structural equation models. Journal of the Academy of Marketing Science, 16, 74-94. http://dx.doi.org/10.1007/ BF02723327

Bamundo, P.J., \& Kopelman, R.E. (1980). The moderating effects of occupation, age, and urbanization on the relationship between job satisfaction and life satisfaction Journal of Vocational Behavior, 17(1), 106-123. http://dx.doi.org/10.1016/0001 8791(80)90020-2

Bastug, G., \& Duman, S. (2010). Examining life satisfaction level depending on physical activity in Turkish and German societies. Procedia - Social and Behaviora Sciences, 2(2), 4892-4895. http://dx.doi.org/10.1016/j.sbspro.2010.03.790

Bender, K.A., \& Heywood, J.S. (2006). Job satisfaction of the highly educated: The role of gender, academic tenure, and earnings. Scottish Journal of Political Economy, 53(2), 254-279. http://dx.doi.org/10.1111/j.1467-9485.2006.00379.x

Bernhardt, K.L., Donthu, N., \& Kennett, P.A. (2000). A longitudinal analysis of satisfaction and profitability. Journal of Business Research, 47, 161-171. http:// dx.doi.org/10.1016/S0148-2963(98)00042-3

Buetell, N. (2006). Life satisfaction, a Sloan Work and Family Encyclopedia entry. In Sloan Work-Family Encyclopedia (pp. 1125-1127). Boston, MA: Boston College.

Bunton, S.A., \& Corrice, A.M. (2011). Evolving workplace flexibility for U.S. medical school tenure-track faculty. Academic Medicine, 86(4), 481-485. http://dx.doi. org/10.1097/ACM.0b013e31820ce51d

Carifio, J., \& Perla, R.J. (2007). Ten common misunderstandings, misconceptions, persistent myths and urban legends about Likert scales and Likert response formats and their antidotes, Journal of Social Sciences, 3(3), 106-116.

Cech, E.A., \& Blair-Loy, M. (2014). Consequences of flexibility stigma among academic scientists and engineers. Work and Occupations, 41(1), 86-110. http://dx.doi. org/10.1177/0730888413515497

Chang, E.C., \& Sanna, L.J. (2001). Optimism, pessimism, and positive and negative affectivity in middle-aged adults: A test of a cognitive-affective model of psychological adjustment. Psychology and Aging, 16(3), 524-531.http://dx.doi. org/10.1037/0882-7974.16.3.524

Chi, C.G., \& Gursoy, D. (2009). Employee satisfaction, customer satisfaction and financial performance: An empirical examination. International Journal of Hospitality Management, 28, 245-253. http://dx.doi.org/10.1016/j. ijhm.2008.08.003

Chin, W.W. (1998). Issues and opinion on structural equation modelling. MIS Quarterly, 22(1), 7-16.

Chung, K.C., Song, J.W., Kim, H.M., Woolliscroft, J.O., Quint, E.H., Lukacs, N.W. et al. (2010). Predictors of job satisfaction among academic faculty members: Do instructional and clinical staff differ? Medicine Education, 44(10), 985-995. http://dx.doi.org/10.1111/j.1365-2923.2010.03766.x 
Clark, B. (2004). Sustaining change in universities. Maidenhead, UK: SRHE/Open University Press.

Clark, L.A., \& Watson, D. (1995). Constructing validity: basic issues in scale development. Psychological Assessment, 7(3), 309-319. http://dx.dol. org/10.1037/1040-3590.7.3.309

Constitution of South Africa (1996). Chapter 2, Bill of rights. Retrieved October 26, 2013, from: http://www.info.gov.za/documents/constitution/1996/96cons2.htm $-16$

Council on Higher Education (2011). Report of the Higher Education Quality Committee (HEQC) to the University of Venda, Pretoria, South Africa, 10 May.

Cummings, T.G., \& Worley, C.G. (2005). Organisational development and change. Cincinnati, OH: Thomson South-Western College Publishing.

Daly, C.J., \& Dee, J.R. (2006). Greener pastures: Faculty turnover intent in urban public universities. Journal of Higher Education, 77(9), 59-64.

Denis, D.J. (2011). Multiple linear regression using SPSS. Retrieved August 20, 2012 from http://psychweb.psy.umt.edu//denis/datadecision/front/stat_II2011/ psyx_521_multiple_regresson_part_II.pdf

Diener, E.D., Emmons, R.A., Larsen, R.J., \& Griffin, S. (1985). The satisfaction with life scale. Journal of Personality Assessment, 49(1), 71-75.

Dockel, A. (2003). The effect of retention factors on organisational commitment: An investigation of high technology employees. Master's thesis, Faculty of Economics and Management Sciences. University of Pretoria, South Africa.

Drago, R., Colbeck, C.L., Stauffer, K.D., Pirretti, A., Burkum, K., Fazioli, J. et al. (2006). The avoidance of bias against caregiving: The case of academic

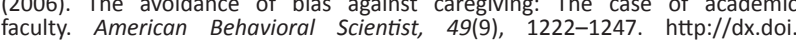
org/10.1177/0002764206286387

Eskildsen, J.K., \& Dahlgaard, J.J. (2000). A causal model for employee satisfaction. Total Quality Management, 11(8), 1081-1094. http://dx.doi. org/10.1080/095441200440340

Faragher, E.B., Cass, M., \& Cooper, L.C. (2005). The relationship between job satisfaction and health: A meta-analysis. Journal of Occupational and Environmental Medicine, 62, 105-112. http://dx.doi.org/10.1136/oem.2002.006734

Field, A. (2009). Discovering statistics using SPSS (and sex and drugs and rock ' $n$ ' roll). Los Angeles, CA: Sage.

Filiz, Z. (2013). An analysis of the levels of job satisfaction and life satisfaction of the academic staff. Social Indicators Research. Retrieved October 15, 2013, from http://link.springer.com/article/10.1007\%2Fs11205-013-0319-6

Fincham, J.E. (2008). Response rates and responsiveness for surveys, standards, and the journal. American Journal of Pharmaceutical Education, 72(2), 43-55. http:// dx.doi.org/10.5688/aj720243

Finn, C.P. (2001). Autonomy: An important component for nurses' job satisfaction International Journal of Nursing Studies, 38(30), 349-357. http://dx.doi. org/10.1016/S0020-7489(00)00065-1

Friedman, D.E. (2012). Workplace flexibility: A guide for companies. Retrieved Octobe 12, 2013, from http://familiesandwork.org/3w/tips/downloads/companies.pdf

Georgellis, Y., Lange, T., \& Tabvuma, V. (2012). The impact of life events on job satisfaction. Journal of Vocational Behavior, 80, 464-473. http://dx.doi. org/10.1016/j.jvb.2011.12.005

Ghiselli, R.E., La Lopa, J.M., \& Bai, B. (2001). Job satisfaction, life satisfaction, and turnover intent among food-service managers. Cornell Hotel and Restauran Administration Quarterly, 42(2), 28-37. http://dx.doi.org/10.1016/s00108804(01)80036-7

Goslin, P.A. (2005). Managing employee satisfaction of volunteers in South African sport. African Journal for Physical Health Education, 12(1), 1-40.

Goulden, M., Mason, M., \& Frasch, K. (2011). Work, family, and workplace flexibility: Keeping women in the science pipeline. The Annals of the American Academy of Political and Social Science, 638(141). Retrieved October 17, 2013, from https:// Political and Social Science, 638(141). Retrieved October 17, 2013, from https:// $\mathrm{d}=1 \&$ doctype=cite\&docid=638+Annals+141\&srctype=smi\&srcid=3B15\&key=1a2 $\mathrm{d}=1 \&$ doctype $=$ cite $\&$ docid $=638+$ Ann
a858b73d5961f52e264962c7c3c96.

Graves, L.M., Ohlott, P.J., \& Ruderman, M.N. (2007). Commitment to family roles: Effects on manager's attitudes and performance. Journal of Applied Psychology, 92(1), 44-56. http://dx.doi.org/10.1037/0021-9010.92.1.44

Green, S.B. (1991). How many subjects does it take to do a regression analysis? Multivariate Behavioral Research, 26, 499-510. http://dx.doi.org/10.1207/ s15327906mbr2603_7

Griffin, M.A., Patterson, M.G., \& West, M.A. (2001). Job satisfaction and teamwork: The role of supervisor support. Journal of Organizational Behaviour, 22, 537-550. http://dx.doi.org/10.1002/job.101

Guney, G., Kalafat, T., \& Boysan, M. (2010). Dimensions of mental health: Life satisfaction, anxiety and depression: A preventive mental health study in Ankara University students' population. Procedia - Social and Behavioral Sciences, 2(2), 1210-1213. http://dx.doi.org/10.1016/j.sbspro.2010.03.174

Heller, D., Judge, T.A., \& Watson, D. (2002). The confounding role of personality and trait affectivity in the relationship between job and life Satisfaction. Journal of Organizational Behavior, 23, 815-835. http://dx.doi.org/10.1002/job.168

Herzberg, F. (1966). Work and the nature of man. Cleveland, OH: World Publishing.

Holub, T. (2003). Contract faculty in higher education. ERIC Digest, 3, 482-556.

Hulland, J. (1999). Use of Partial Least Squares (PLS) in strategic management research: A review of four recent studies. Strategic Management Journal, 20(2), 195-204. http://dx.doi.org/10.1002/(SICI)1097-0266(199902)20:2\%3C195::AIDSMJ13\%3E3.0.CO;2-7

Hyland, K. (2009). Academic socialization. New York, NY: The Tower Building.
Ignat, A., \& Clipa, O. (2012). Teachers' satisfaction with life, job satisfaction and their emotional intelligence. Procedia - Social and Behavioral Sciences, 33, 498-502. $\mathrm{http}: / / \mathrm{dx}$.doi.org/10.1016/j.sbspro.2012.01.171

Ilies, R., Wilson, K.S., \& Wagner, D.T. (2009). The spillover of daily job satisfaction onto employees' family lives: The facilitating role of work-family integration AMJ.2009.36461938

Jansen, J. (2004). Changes and continuities in South Africa's higher education system. 1994-2004. In L. Chisholm (Ed.), Changing class: Education and social change in post-apartheid South Africa (pp. 293-314). Cape Town, South Africa: HSRC Press. http://dx.doi.org/10.4314/sajhe.v17i3.25399

Jansen, L. (2013). SA academics among highest paid. IOL News, 30 September. Retrieved October 21, 2013, from http://www.iol.co.za/news/south-africa/saacademics-among-highest-paid-1.1584680 - .UmaJD3ASaSo

Johnsrud, L.K. (2002). Measuring the quality of faculty and administrative work life: Implications for college and university campuses. Research in Higher Education 43(3), 379-395. http://dx.doi.org/10.1023/A:1014845218989

Judge, T.A., Thoresen, C.J., Bono, J.E., \& Patton. G.K. (2001). The job satisfaction-job performance relationship: A qualitative and quantitative review. Psychological Bulletin, 127(3), 376-407. http://dx.doi.org/10.1037/0033-2909.127.3.376

Jusoff, K., Hussein, Z.H., Ju, S.Y., \& Din, M.S.H. (2009). The life satisfaction of academic and non-academic staff in a Malaysian higher education institution. International Education Studies, 2(1), 143-150. http://dx.doi.org/10.5539/ies.v2n1p143

Kalisch, B.J., Lee, H., \& Rochman, M. (2010). Nursing staff teamwork and job satisfaction. Journal of Nursing Management, 18, 938-947. http://dx.doi. org/10.1111/j.1365-2834.2010.01153.x

Kgosana, C. (2011). Lack of black academics lamented. IOL News, 24 February. Retrieved October 25, 2013, from http://www.iol.co.za/news/south-africa/lackof-blackacademics-lamented.

Kipkebut, D.J. (2010). Organisational commitment and job satisfaction in highe educational institutions: The Kenyan case. PhD thesis, Business School, Middlesex University, United Kingdom.

Koohsar, A.K.H., \& Bonab, B.H. (2011). Relation between quality of attachment and life satisfaction in high school administrators. Procedia - Social and Behavioral Sciences, 30, 954- 958. http://dx.doi.org/10.1016/j.sbspro.2011.10.185

Koys, D. (2003). How the achievement of human resources goals drives restaurant performance. Cornell Hotel and Restaurant Administration Quarterly, 44(1), 1724. http://dx.doi.org/10.1016/S0010-8804(03)90032-2

Lent, R.W., Taveira, M., B, Sheu, H.B., \& Singley, D. (2009). Social cognitive predictors of academic adjustment and life satisfaction in Portuguese college students: $A$ longitudinal analysis, Journal of Vocational Behavior, 74, 190-198. http://dx.doi. org/10.1016/j.jvb.2008.12.006

Leo, C., Bennett, R., \& Hartel, C.E.J. (2005). Cross-cultural differences in consumer decision-making styles. Cross-Cultural Management, 12(3), 32-62. http://dx.doi. org/10.1108/13527600510798060

Loscocco, K.A., \& Roschelle, A.R. (1991). Influence on the quality of work and nonwork life: Two decades in review. Journal of Vocational Behaviour, 39(1), 182225. http://dx.doi.org/10.1016/0001-8791(91)90009-B

Mafini, C., Surujlal, J., \& Dhurup, M. (2012). Examining the relationship between job satisfaction, life satisfaction and quality of work life among municipal sports officers. African Journal for Physical, Health Education, Recreation and Dance, December (Supplement), 183-201.

Malhotra, N.K. (2010). Marketing research: an applied orientation. (6th edn.) Eaglewood Cliffs, NJ: Prentice-Hall. http://dx.doi.org/10.1108/S15486435(2010)0000007010

Martensen, A., \& Gronholdt, L. (2001). Using employee satisfaction measurement to improve people management: An adaptation of Kano's quality types. Tota Quality Management, 12(8), 949-957.

Matzler, K., \& Renzl, B. (2007). Assessing asymmetric effects in the formation of employee satisfaction. Tourism Management, 28, 1093-1103. http://dx.doi. org/10.1016/j.tourman.2006.07.009

Mayekiso, TV., \& Snodgrass, L. (2008). Managing diversity in transforming institutions of higher education: The case of Nelson Mandela Metropolitan University, South Africa. International Journal of Diversity in Organizations, Communities and Nations, 8(5), 123-130.

Mederer, H., \& Silver, B. (2011). Workplace flexibility and faculty success: What a chair needs to know. Retrieved October 21, 2013, from http://www.uri.edu/worklife/ assets/Resources/Presentations/Chairs' Work-Life workshop HM.pdf

Mokoditoa, J.C. (2011). Academic staff recruitment and retention strategies at the University of Limpopo. Master's dissertation, Faculty of Management Sciences and Law, University of Limpopo, South Africa. Retrieved October 17, 2013, from http://ul.netd.ac.za/bitstream/10386/393/1/Mokoditoa, J. M..pdf

Muller, S. (2013). No replacement for ageing brains: As older academics retire, there seems to be little deliberate action to bring new blood on board. Mail \& Guardian, 04 October. Retrieved October 22, 2013, from http://mg.co.za/article/2013-1004-no-replacement-for-ageing-brains

Ngethe, J, M., Iravo, M.E., \& Namusone, G.S. (2012). Determinants of academic staff retention in public universities in Kenya: Empirical review. International Journal of Humanities and Social Science, 2(13), 205-212.

Nickerson, A., \& Nagle, R.J. (2005). Parent and peer attachment in late childhood and early adolescence. Journal of Early Adolescence, 25, 223-249. http://dx.doi. org/10.1177/0272431604274174

Nieuwenhuizen, C. (2011). Academic staff and employment equity profile in Business Management departments at universities in South Africa. African Journal of Business Management, 5(16), 7006-7016. 
Ogbonna, E., \& Harris, L.C. (2004). Work intensification and emotional labour among UK university lecturers: An exploratory study. Organization Studies, 25(7), 1185UK university lecturers: An exploratory study. Organ
1203. http://dx.doi.org/10.1177/0170840604046315

Olson, K. (2010). An examination of questionnaire evaluation by expert reviewers. Retrieved October 04, 2013, from http://digitalcommons.unl.edu/cgi/viewcontent. cgi?article $=1138 \&$ context $=$ sociologyfacpub

Oshagbemi, T. (1996). Job satisfaction of UK academics. Education Management and Administration, 24(4), 389-400. http://dx.doi.org/10.1177/0263211X9602400405

Ozer, B.U., \& Saçke, M. (2011). Effects of academic procrastination on college students' life satisfaction. Procedia Social and Behavioral Sciences, 12, 512-519. http:// dx.doi.org/10.1016/j.sbspro.2011.02.063

Palmer, B., Donaldson, C., \& Stough, C. (2002). Emotional intelligence and life satisfaction. Personality and Individual Difference, 33, 1091-1100. http://dx.doi. org/10.1016/S0191-8869(01)00215-X

Phillips, J.J., \& Connell, A.O. (2003). Managing employee retention: A strategic accountability approach. Burlington, NC: Franklin Covey. http://dx.doi.org/10.1016/ B978-0-7506-7484-3.50019-6

Pienaar, C., \& Bester, C.L. (2006). Typical career dilemmas of academic staff during the early career phase within a changing South African higher education institution. South African Journal of Education, 26(4), 581-594.

Rasool, F., \& Botha, C.J. (2011). The nature, extent and effect of skills shortages on skills migration in South Africa. SA Journal of Human Resource Management/SA Tydskrif vir Menslikehulpbronbestuur, 9(1), Art. \#287, 12 pages. http://dx.doi.org/10.4102/ sajhrm.v9i1.287

Riddell, S., Edward, S., Raffe, R., Tett, L., \& Weedon, E. (2008). An overview of the policy and delivery base for skills development in Scotland. Retrieved October 03, 2013, from http://www.docs.hss.ed.ac.uk/education/creid/Briefings/Briefing14.pdf

Riley, M. (2009). Keeping part-time employees motivated: Focusing on job satisfaction to increase productivity. New York, NY: Reinholdt.

Rode, J.C. (2004). Job satisfaction and life satisfaction revisited: A longitudinal test of an integrated model. Human Relations, 57(9), 1205-1231. http://dx.doi. org/10.1177/0018726704047143

Rosser, V. (2004). Faculty members' intention to leave: A national study on their worklife and satisfaction. Research in Higher Education, 45(3), 285-309. http://dx.doi. org/10.1023/B:RIHE.0000019591.74425.f1

Saari, L.M., \& Judge, T.A. (2004). Employee attitudes and job satisfaction. Human Resource Management, 43, 395-407. http://dx.doi.org/10.1002/hrm.20032

Samuel, M.O., \& Chipunza, C. (2013). Attrition and retention of senior academics at institutions of higher learning in South Africa: The strategies, complexities and realities. Journal of Social Science, 35(2), 97-109.

Schulze, S. (2006). Factors influencing the job satisfaction of academics in highe education. South African Journal of Higher Education, 20(2), 318-335.

Shields, M. (2006). Unhappy on the job. Health Report, 17(4), 82-83.

Shoaib, M., Noor A., Tirmizi, S., \& Bashir, S. (2009). Determinants of employee retention in telecom sector of Pakistan. In Proceedings of the 2nd CBRC, Lahore, Pakistan, 14 November.

Slabbert, F. (2003). Is academic freedom still an issue in the new South Africa? Retrieved October 26, 2013, from http://www.uct.ac.za/downloads/news.uct.ac.za/lectures/ tbdavie/acfree_newsa.pdf

Spector, P.E. (1997). Job satisfaction: Application, assessment, causes and consequences London, UK: Sage.

SSesanga, K., \& Garret, R.M. (2005). Job satisfaction of university academics: Perspectives from Uganda. Higher Education, 50, 33-56. http://dx.doi.org/10.1007/ s10734-004-6346-0
Story, D.A., Ranong, V., \& Jones, D. (2011). Inconsistent survey reporting in anesthesia journals. Anesthesia and Analgesia, 113(3), 591-595.

Taylor, S., \& Hansen, H. (2005). Finding form: Looking at the field of organizational aesthetics. Journal of Management Studies, 42(6), 1211-1231. http://dx.doi. org/10.1111/j.1467-6486.2005.00539.x

Tettey, J.W. (2006). Staff retention in African universities: Elements of a sustainable strategy. Washington, DC: World Bank.

Turkyilmaz, A., Akman, G., Ozkan, C., \& Pastuszak, Z. (2011). Empirical study of public sector employee loyalty and satisfaction. Industrial Management \& Data Systems, 111(5), 675-696. http://dx.doi.org/10.1108/02635571111137250

Turman, P. (2003). The impact of coaching techniques on team cohesion in the small group sport setting. Journal of Sport Behavior, 26(1), 63-81.

Volkwein, J. F., \& Zhou, Y. (2003). Testing a model of administrative job satisfaction. Research in Higher Education, 44(2), 149-171. http://dx.doi. org/10.1023/A:1022099612036

Volpe, M.R., \& Chandler, D. (2001). Resolving conflicts in institutions of higher education: Challenges for PR academics. Negotiation Journal, 17(3), 245-255. http://dx.doi.org/10.1111/j.1571-9979.2001.tb00239.x

Wangenheim, F.W., Evanschitzky, H., \& Wunderlich, M. (2007). Does the employeecustomer satisfaction link hold for all employee groups? Journal of Business Research, 14(3), 304-348.

Weiss, H.M. (2002). Deconstructing job satisfaction: Separating evaluations, beliefs and affective experiences. Human Resource Management Review, 12, 173-194. $\mathrm{http}: / / \mathrm{dx}$.doi.org/10.1016/S1053-4822(02)00045-1

West, P.W.A. (2006). Conflict in higher education and its resolution. Higher Education Quarterly, 60(2), 187-197. http://dx.doi.org/10.1111/j.1468-2273.2006.00316.x

Westman, M. (2006). Models of work-family interactions: Stress and strain crossover. In R.K. Suri (Ed.), International encyclopedia of organizational behavior (pp. 498522). New Delhi, India: Pentagon Press.

White, J.W., \& Lowenthal, P.R. (2011). Minority college students and tacit 'codes of power': Developing academic discourses and identities. The Review of Higher Education, 34(2), 283-318. http://dx.doi.org/10.1353/rhe.2010.0028

Ye, S., Yu, L., \& Li, K. (2012). A cross-lagged model of self-esteem and life satisfaction: Gender differences among Chinese university students. Personality and Individual Differences, 52(4), 546-551. http://dx.doi.org/10.1016/j. paid.2011.11.018

Yee, R. W. Y., Yeung, A. C.L., \& Cheng, T. C.E. (2008). The impact of employee satisfaction on quality and profitability in high-contact service industries. Journal of Operations Management, 26(5), 651-668. http://dx.doi.org/10.1016/j. jom.2008.01.001

Zarafshani, K., \& Alibaygi, A.H. (2008). Predictors of job satisfaction among academics in Iranian university. NACTA Journal. Retrieved October 19, 2013, from http:// www.nactateachers.org/attachments/article/178/Kiumars_NACTA_Journal_ December_2008.pdf

Zhang, J., \& Howell, R.T. (2011). Do time perspectives predict unique variance in life satisfaction beyond personality traits? Personality and Individual Differences, 50(8), 1261-1266. http://dx.doi.org/10.1016/j.paid.2011.02.021

Zhao, X.R., Qu, H., \& Ghiselli, R. (2011). Examining the relationship of work-family conflict to job and life satisfaction: A case of hotel sales managers. International Journal of Hospitality Management, 30(1), 46-54. http://dx.doi.org/10.1016/j. ijhm.2010.04.010

Zohreh, S., Nadergholi, G., \& Alia, K. (2011). Developing a research university in Iranian higher education system: A model presentation. Procedia Social and Behavioral Sciences, 15, 2259-2263. http://dx.doi.org/10.1016/j.sbspro.2011.04.090 